\title{
Purification and biochemical characterization of an extracellular serine peptidase from Aspergillus terreus
}

\author{
Rafael Tage Biaggio, Ronivaldo Rodrigues da Silva, Nathalia Gonsales da \\ Rosa, Rodrigo Simões Ribeiro Leite, Eliane Candiani Arantes, Tatiana Pereira \\ de Freitas Cabral, Maria A. Juliano, Luiz Juliano \& Hamilton Cabral
}

To cite this article: Rafael Tage Biaggio, Ronivaldo Rodrigues da Silva, Nathalia Gonsales da Rosa, Rodrigo Simões Ribeiro Leite, Eliane Candiani Arantes, Tatiana Pereira de Freitas Cabral, Maria A. Juliano, Luiz Juliano \& Hamilton Cabral (2016) Purification and biochemical characterization of an extracellular serine peptidase from Aspergillus terreus, Preparative Biochemistry and Biotechnology, 46:3, 298-304, DOI: 10.1080/10826068.2015.1031387

To link to this article: https://doi.org/10.1080/10826068.2015.1031387

Accepted author version posted online: 01

Apr 2015.

Published online: 14 Apr 2016.

Submit your article to this journal $\pi$

Џll Article views: 160

View Crossmark data $₫$

Citing articles: 9 View citing articles $\widetilde{ }$ 


\title{
Purification and biochemical characterization of an extracellular serine peptidase from Aspergillus terreus
}

\author{
Rafael Tage Biaggioa, Ronivaldo Rodrigues da Silva ${ }^{b}$, Nathalia Gonsales da Rosa ${ }^{a}$, Rodrigo Simões Ribeiro Leite ${ }^{c}$, \\ Eliane Candiani Arantes ${ }^{d}$, Tatiana Pereira de Freitas Cabral ${ }^{e}$, Maria A. Juliano ${ }^{f}$, Luiz Juliano ${ }^{f}$, and Hamilton Cabral ${ }^{a}$

\begin{abstract}
aDepartment of Pharmaceutical Sciences, Faculty of Pharmaceutical Sciences of Ribeirão Preto, University of São Paulo, Ribeirão Preto, Brazil; ${ }^{b}$ Institute of Biosciences, Letters and Exact Sciences, Universidade Estadual Paulista, São José do Rio Preto, Brazil; 'Faculty of Biological and

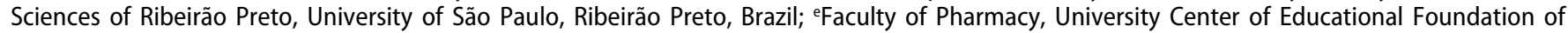
Barretos, Barretos, Brazil; 'Department of Biophysics, Paulista School of Medicine, Federal University of São Paulo, São Paulo, Brazil
\end{abstract} \\ Environmental Sciences, Federal University of Grande Dourados, Dourados, Brazil; ${ }^{d}$ Department of Physics and Chemistry, Faculty of Pharmaceutical
}

\section{ABSTRACT}

Peptidases are important because they play a central role in pharmaceutical, food, environmental, and other industrial processes. A serine peptidase from Aspergillus terreus was isolated after two chromatography steps that showed a yield of $15.5 \%$. Its molecular mass was determined to be $43 \mathrm{kD}$, by sodium dodecyl sulfate polyacrylamide gel electrophoresis (SDS-PAGE). This peptidase was active between $\mathrm{pH} 5.0$ to 8.0 and had maximum activity at $\mathrm{pH} 7.0$, at $45^{\circ} \mathrm{C}$. When exposited with $1 \mathrm{M}$ of urea, the enzyme maintained $100 \%$ activity and used azocasein as substrate. The N-terminal (first 15 residues) showed 33\% identity with the serine peptidase of Aspergillus clavatus ES1. The kinetics assays showed that subsite $\mathrm{S}_{2}$ did not bind polar basic amino acids (His and Arg) nonpolar acidic amino acids (Asp and Glu). The subsite $S_{1}$ showed higher catalytic efficiency than the $S_{2}$ and $S_{3}$ subsites.

\section{KEYWORDS}

Aspergillus; enzyme kinetics; filamentous fungi; $\mathrm{N}$-terminal sequence; protease; protein

\section{Introduction}

Peptidases belong to the class of hydrolases that catalyze the peptide bonds of proteins and peptides, and they play an important nutritional and regulatory role in different organisms. Extracellular peptidases act mainly in protein and polypeptide degradation, for production of energy and biosynthesis precursor by fungi. ${ }^{[1]}$

Peptidases are enzymes that occupy a central position due to their applications in both the physiological and commercial fields. ${ }^{[2]}$ They comprise an enzyme group that represents a quarter of the worldwide sale of enzymes. These enzymes are applied in detergents, meat tenderizers, leather treatment, the dairy industry, waste treatment, and others. ${ }^{[3,4]}$

Hydrolyzed proteins are important products in the food and nutraceutical industries for two reasons. The first reason is that they promote improved nutrition, bioactivity, and functional properties of the food such as solubility, digestibility, sensory quality, and antioxidant capacity. The second reason is that the enzymatic hydrolysis has advantages over the chemical process, because the enzyme is more specific, more controllable, and it does not harm the environment. ${ }^{[5]}$

The genus Aspergillus is known for its ability to secrete high levels of enzyme to the environment, and several enzymes secreted by this genus have been widely used in the food and beverages industries for decades. ${ }^{[6]}$

Aspergillus terreus is known to produce extracellular enzymes with proteolytic activity. Previous findings indicate that metallopeptidases produced promote postsecretional proteolysis of high-molecular-mass cellulases into smaller enzymes of the cellulolytic complex. ${ }^{[7]}$

The aim of this work is to describe the biochemical characterization and kinetics parameters of a purified serine peptidase from Aspergillus terreus.

\section{Experimental}

\section{Microorganism and maintenance}

Aspergillus terreus was maintained on potato-dextrose agar slants at $30^{\circ} \mathrm{C}$ for 7 days. After this period, the slants were stored at $4^{\circ} \mathrm{C}$. The spores were resuspended through addition of sterile water and quantified in a Neubauer chamber.

\section{Submerged fermentation (SmF)}

Peptidase production by submerged fermentation $(\mathrm{SmF})$ was performed in Erlenmeyer flasks $(250 \mathrm{~mL})$ and consisted of $50 \mathrm{~mL}$ of liquid medium, containing $0.2 \% \quad \mathrm{KH}_{2} \mathrm{PO}_{4}, 0.7 \%$ $\mathrm{K}_{2} \mathrm{HPO}_{4}, 0.01 \% \quad \mathrm{MgSO}_{4} \cdot 7 \mathrm{H}_{2} \mathrm{O}, 0.1 \%$ yeast extract, $0.5 \%$ $\mathrm{NaCl}$, and $0.5 \%$ casein, as reported in Tran and Nagano, ${ }^{[8]}$ which used also the reagents citrate $\cdot 2 \mathrm{H}_{2} \mathrm{O} 0.05 \%$, gelatin $0.3 \% \mathrm{CaCl}_{2} \cdot 2 \mathrm{H}_{2} \mathrm{O}$, glucose $1 \%$, and polypeptone $1 \%$, at $\mathrm{pH}$ 7.4. The medium was adjusted to $\mathrm{pH} 6.0$ and the flasks were autoclaved for $15 \mathrm{~min}$ at $121^{\circ} \mathrm{C}$.

The $\mathrm{SmF}$ medium was inoculated with $5 \times 10^{6}$ spores $/ \mathrm{mL}$ from A. terreus and incubated in a shaker at $30^{\circ} \mathrm{C}$ and $120 \mathrm{rpm}$, for $72 \mathrm{hr}$. The material was filtered with Whatman paper number 1 and centrifuged at $8000 \times \mathrm{g}$ for $20 \mathrm{~min}$, at $4^{\circ} \mathrm{C}$. 


\section{Determination of proteolytic activity}

Proteolytic activity was determined according to the protocol described by Sarath et al., ${ }^{[9]}$ with modifications (the original protocol used filtration in Whatman paper number 3).

The reaction mixture was composed of $1 \mathrm{~mL}$ of $1 \%(\mathrm{w} / \mathrm{v})$ casein (Sigma) in HEPES buffer $(50 \mathrm{mM}, \mathrm{pH} 7)$ and $0.2 \mathrm{~mL}$ of the enzyme solution. The reaction was carried out at $40^{\circ} \mathrm{C}$ and incubated for $60 \mathrm{~min}$. The enzymatic reaction was stopped by the addition of $0.6 \mathrm{~mL}$ of $10 \%$ trichloroacetic acid (TCA). Reaction and blank tubes were centrifuged at $10,000 \times \mathrm{g}$ for $15 \mathrm{~min}$, at $25^{\circ} \mathrm{C}$. The absorbance of the supernatant for the reaction tubes was measured by spectrophotometer at $280 \mathrm{~nm}$, against their respective blank tubes. Activity units (AU) were expressed as the amount of enzyme required to promote the liberation of $1 \mu \mathrm{mol}$ tyrosine/min, under defined assay conditions. ${ }^{[9]}$

Biochemical studies were performed using $1 \%$ azocasein as a substrate, according to the protocol described by Ducros et al. ${ }^{[10]}$ with modifications (that used substrate $0.3 \%$ and TCA $10 \%$ concentration). The reaction mixture consisted of $0.1 \mathrm{~mL}$ of purified enzyme, $0.1 \mathrm{~mL}$ of HEPES buffer $(50 \mathrm{mM}$, $\mathrm{pH} 7$ ), and $0.2 \mathrm{~mL}$ of $1 \%$ azocasein. The mixture was incubated at $40^{\circ} \mathrm{C}$ for $10 \mathrm{~min}$, and the reaction was stopped by the addition of $0.8 \mathrm{~mL} 20 \%$ TCA. Reaction and blank tubes were centrifuged at $10,000 \times \mathrm{g}$ for $15 \mathrm{~min}$ at $25^{\circ} \mathrm{C}$, and $0.8 \mathrm{~mL}$ of supernatant was harvested and transferred to a clean tube; then $0.9 \mathrm{~mL}$ of $1 \mathrm{M}$ sodium hydroxide was added to the supernatant. The tubes were shaken and the absorbance was measured in a spectrophotometer at $440 \mathrm{~nm}$ and compared with the respective blank tubes. Activity units were defined as the amount of enzyme required to yield an increase of $0.001 \mathrm{~A}_{440 \mathrm{~nm}}$ under the conditions of the assay as described by Morita et al. ${ }^{[1]}$ with modifications (Morita et al. used a wavelength of $340 \mathrm{~nm}$ ).

Protein concentration was determined according to the Bradford method, ${ }^{[12]}$ using bovine serum albumin as a standard.

\section{Purification: Precipitation by ethanol, gel filtration, and ion exchange chromatography}

The enzyme obtained by the fermentation process was precipitated and partially fractionated with ethanol $92.8^{\circ} \mathrm{GL}$ (about $70 \% \mathrm{v} / \mathrm{v}$ ) at a ratio of $1: 3$ (enzymatic extract:ethanol). The material was maintained at $-20^{\circ} \mathrm{C}$ overnight and then it was precipitated by centrifugation at $10,000 \times \mathrm{g}$ for $20 \mathrm{~min}$, at $4^{\circ} \mathrm{C}$. The precipitate was dissolved in sodium acetate buffer (50 $\mathrm{mM}$, pH 5.5), named buffer A.

After being dissolved in buffer $\mathrm{A}$, the precipitate was subjected to gel filtration in a Sephadex G-50 column $(100 \mathrm{~cm} \times 2.5 \mathrm{~cm})$ previously equilibrated with $50 \mathrm{mM} \mathrm{NaCl}$ in buffer $\mathrm{A}$, and the elution was performed with the same buffer. Fractions of $5 \mathrm{~mL}$ were collected at a flow rate of $0.5 \mathrm{~mL} /$ min. Protein content was measured at $280 \mathrm{~nm}$ and the proteolytic activities presented by the fractions were determined, as previously described. Fractions containing proteolytic activity were pooled and dialyzed in BICINE buffer $(30 \mathrm{mM}$, pH 9), named buffer B.

The pooled dialyzed enzyme was subjected to ion-exchange chromatography on a Q-Sepharose column $(15 \mathrm{~cm} \times 1.5 \mathrm{~cm})$ equilibrated with buffer B (30 mM, pH 9). Elution was performed with a gradient containing 0 to $500 \mathrm{mM}$ of $\mathrm{NaCl}$ in buffer B. Fractions of $5 \mathrm{~mL}$ were collected at a flow rate of $0.5 \mathrm{~mL} / \mathrm{min}$. Protein content was measured at $280 \mathrm{~nm}$ and the proteolytic activity presented by the fractions was determined as previously described. Fractions containing proteolytic activity were pooled and dialyzed in ultrapure water at $4^{\circ} \mathrm{C}$ for $24 \mathrm{hr}$.

\section{Sodium dodecyl sulfate polyacrylamide gel electrophoresis}

Certification of purity of the peptidase was verified by sodium dodecyl sulfate polyacrylamide gel electrophoresis (SDS-PAGE), according to the protocol described by Laemmli. ${ }^{[13]}$ The running gel was $12 \%$, and the stacking gel, $4 \%$ polyacrylamide. Staining was performed according to Blum et al. ${ }^{[14]}$

\section{Physical-chemical characteristics}

Biochemical studies were determined using $1 \%$ azocasein as a substrate, according to the protocol described by Ducros et al. ${ }^{[10]}$ with modifications.

\section{Determination of $\mathrm{pH}$ and temperature effects}

The effect of $\mathrm{pH}$ on the proteolytic activity of the purified peptidase was determined at different $\mathrm{pH}$ values, utilizing the following buffers: acetate ( $\mathrm{pH} 4.5$ and 5.0), MES ( $\mathrm{pH} 5.5$,

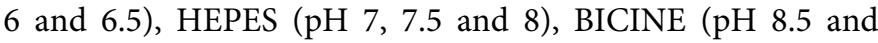
9), and CAPS ( $\mathrm{pH} 9.5,10$ and 10.5), all at final concentrations of $50 \mathrm{mM}$ and using $1 \%$ azocasein as substrate at $40^{\circ} \mathrm{C}$.

The influence of temperature on the activity of purified peptidase was investigated in the range of $25^{\circ} \mathrm{C}$ to $70^{\circ} \mathrm{C}$, with $5^{\circ} \mathrm{C}$ increments. All experiments were performed using $1 \%$ azocasein as substrate in HEPES buffer (50 $\mathrm{mM}, \mathrm{pH} 7)$.

\section{Determination of inhibitor effect}

The mechanism of enzyme action was determined according to the protocol described by Dunn ${ }^{[15]}$ with modifications (Dunn used the inhibitors E-64 for cysteine protease, pepstatin for aspartic protease, and 1,10-phenantroline for metalloprotease). The inhibitors iodoacetic acid (IAA), phenylmethylsulfonyl fluoride (PMSF), and ethylenediamine tetraacetic acid (EDTA) were used at a final concentration of $10 \mathrm{mM}$. All experiments were performed using $1 \%$ azocasein as substrate in HEPES buffer $(50 \mathrm{mM}, \mathrm{pH} 7)$ at $40^{\circ} \mathrm{C}$.

\section{Determination of surfactant effect}

The effect of anionic sodium lauryl sulfate (SDS) and cationic cetyl trimethyl ammonium bromide (CTAB) surfactants on the proteolytic activity of the purified peptidase was investigated at percentages of $0.1,0.25,0.5,0.75$, and $1 \%$. The peptidase was previously incubated with SDS and CTAB for $5 \mathrm{~min}$, at $40^{\circ} \mathrm{C}$. All experiments were performed using $1 \%$ azocasein as substrate in HEPES buffer $(50 \mathrm{mM}, \mathrm{pH} 7)$ at $40^{\circ} \mathrm{C}$ 


\section{Determination of metal ion effect}

The metal ion effect was determined at a final concentration of $5 \mathrm{mM}$. The peptidase was previously incubated with metal ions $\mathrm{CoCl}_{2}, \mathrm{KCl}, \mathrm{LiCl}, \mathrm{AlCl}_{3}, \mathrm{MgCl}_{2}, \mathrm{BaCl}_{2}, \mathrm{CaCl}_{2}, \mathrm{MnCl}_{2}, \mathrm{CuCl}_{2}$, and $\mathrm{NaCl}$ for $5 \mathrm{~min}$, at $40^{\circ} \mathrm{C}$. All experiments were performed using $1 \%$ azocasein as substrate in HEPES buffer $(50 \mathrm{mM}$, $\mathrm{pH} 7)$ at $40^{\circ} \mathrm{C}$.

\section{Determination of reducing agent effect}

The effect of the reducing agent dithiothreitol (DTT) on the proteolytic peptidase activity was investigated at the concentrations of $5,10,20,40,60,80$, and $100 \mathrm{mM}$. The peptidase was previously incubated with DTT for $5 \mathrm{~min}$ at $40^{\circ} \mathrm{C}$. All experiments were performed using $1 \%$ azocasein as substrate in HEPES buffer $(50 \mathrm{mM}, \mathrm{pH} 7)$, at $40^{\circ} \mathrm{C}$.

\section{Determination of urea effect}

The effect of urea on the proteolytic activity was investigated at concentrations of 50,100,250,500, and $1000 \mathrm{mM}$. The peptidase was previously incubated with urea for $5 \mathrm{~min}$, at $40^{\circ} \mathrm{C}$. All experiments were performed using $1 \%$ azocasein as substrate in HEPES buffer $(50 \mathrm{mM}, \mathrm{pH} 7)$, at $40^{\circ} \mathrm{C}$.

\section{Enzyme kinetics}

The assays were performed in spectrofluorimeter using synthetic FRET peptides with mutations in amino acids residues in $\mathrm{P}_{1}, \mathrm{P}_{2}$, and $\mathrm{P}_{3}$ positions of standard substrate Abz-KLRSSKQ-EDDnp. The substrate Abz-KLXSSKQEDDnp showed mutation in $\mathrm{X}$ (where $\mathrm{X}$ is $\mathrm{D}, \mathrm{E}, \mathrm{F}, \mathrm{H}, \mathrm{I}$, $\mathrm{M}, \mathrm{R}, \mathrm{S}, \mathrm{T}$, and $\mathrm{Y}$ ). The substrate in position $\mathrm{P}_{2}$ (AbzKXFSSKQ-EDDnp) showed mutation in $\mathrm{X}$ (where $\mathrm{X}$ is $\mathrm{D}$, $\mathrm{E}$, F, H, I, M, R, S, T, and Y). In $\mathrm{P}_{3}$, the same substrate, AbzXLRPSKQ-EDDnp, was also used, with mutations in X D, E, F, H, I, M, R, S, and T. The fluorescence was continuously measured and the excitation and emission wavelengths were $320 \mathrm{~nm}$ and $420 \mathrm{~nm}$, respectively. The determination of kinetic parameters was performed under pseudo-first-order conduction $\left([\mathrm{S}]<<\mathrm{k}_{\mathrm{M}}\right)$ to hydrolysis of all substrates. ${ }^{[16]}$ Data were plotted using the computation program GraphPad Prism, using the appropriate equation.

\section{$\mathbf{N}$-terminal amino acid sequence of the enzyme}

The N-terminal sequence was determined using Protein Sequencer PPSQ-33A (Shimadzu Corporation, Kyoto, Japan). The PPSQ-33A system sequentially cleaves the N-terminal amino acids of proteins and peptides using Edman degradation. The PTH-amino acid obtained with Edman
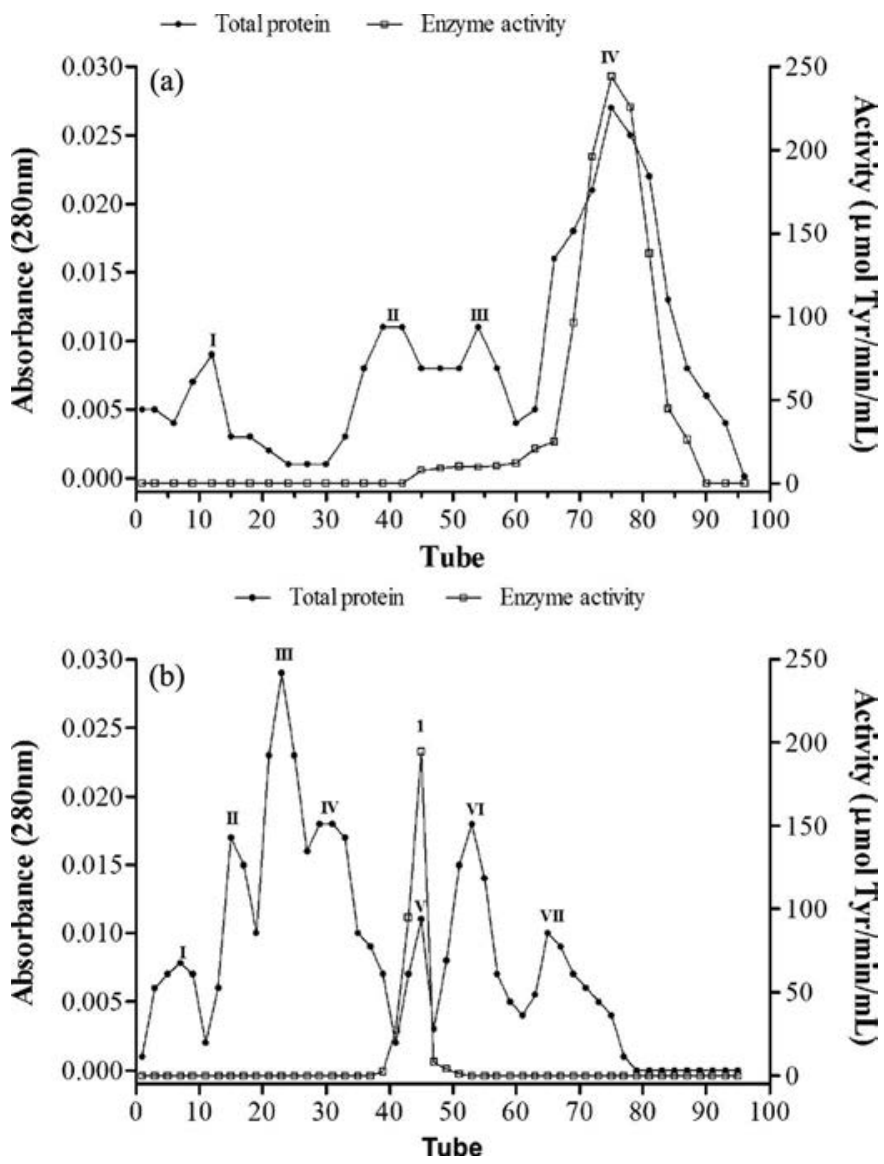

Figure 1. (a) Gel filtration G-50 Sephadex chromatography of the serine peptidase from $A$. terreus. Pooled fractions 35 to 72 . The column was equilibrated and eluted with $50 \mathrm{mM}$ sodium acetate buffer, pH 5.0 , with $50 \mathrm{mM} \mathrm{NaCl}$. (b) Elution profile ion exchange of the peptidase by $A$. terreus from the Q-Sepharose column. The enzyme was eluted with a linear gradient of $\mathrm{NaCl}(0$ to $500 \mathrm{mM})$ in $50 \mathrm{mM}$ bicine buffer, $\mathrm{pH} 8.0$, at a flow rate of $1 \mathrm{~mL} / \mathrm{min}(60 \mathrm{~mL} / \mathrm{hr})$.

degradation (1967) is separated using high-performance liquid chromatography (HPLC) and is identified and quantified, compared to a previously quantified standard, with its retention times and ultraviolet (UV) absorption [17].

\section{Results and discussion}

The purification process of the peptidase from A. terreus was performed in three steps and is presented in Table 1. In the first step, the peptidase was precipitated with ethanol and enzyme recovery was $90.4 \%$, with high specific activity $(2,735 \mathrm{U} / \mathrm{mg}$ of protein). In the second step, gel filtration in Sephadex G-50 was performed and the profile of elution using this resin showed four peaks of protein, and only peak IV showed proteolytic activity (Figure 1a).

We observed a reduction of the specific activity and recovery after gel filtration, when compared with the first step

Table 1. Purification summary of serine peptidase from $A$. terreus produced by submerged fermentation.

\begin{tabular}{lccccc}
\hline Purification steps & Total activity $(\mathrm{U})$ & Total protein $(\mathrm{mg})$ & Specific activity $(\mathrm{U} / \mathrm{mg})$ & Recovery $(\%)$ & 100 \\
\hline Crude extract & 151,200 & 140 & 1080 & 90.4 & 1 \\
Precipitation & 136,750 & 50 & 2735 & 2.5 & 27.5 \\
Sephadex G-50 & 41,600 & 20 & 13080 & 15.5 \\
Q-Sepharose & 23,400 & 18 & 1300 & 1.9 \\
\hline
\end{tabular}


(Table 1). This may be explained by the exposure of the peptidase to room temperature. Sampaio e Silva et al. also observed that the acid peptidase of Aspergillus clavatus lost activity during the purification process. ${ }^{[18]}$

The fraction containing pooled proteolytic activity was subjected to ion-exchange chromatography (Q-Sepharose). Seven peaks of protein were eluted and only peak $\mathrm{V}$ showed proteolytic activity (Figure 1b). The third step of the ion exchange was characterized by high specific activity of $1,300 \mathrm{U} / \mathrm{mg}$ of protein, and in this purification step, the peptidase was purified 1.2 -fold with a recovery of $15.5 \%$ (Table 1 ).

The high specific activity observed in the third step of the ion-exchange chromatography may be explained because the chromatography process was in preserved peptidase at $4^{\circ} \mathrm{C}$ and also by the elimination of other proteins. Another possibility was the elimination of the compound that promotes peptidase inhibition. ${ }^{[19]}$

The peptidase showed only one band with approximate molecular mass of $43 \mathrm{kD}$ in SDS-PAGE (Figure 2). In general, peptidases show microbial molecular mass of approximately 18 to $35 \mathrm{kD}$. ${ }^{[20]}$

The influence of $\mathrm{pH}$ on the activity of the peptidase showed that it is active between $\mathrm{pH} 4.5$ and $\mathrm{pH} 10.5$, but the maximum activity is at pH 7 (Figure 3a). Chakrabarti et al. observed that the peptidase of the fungus $A$. terreus IJIRA 6.2 showed wide activity ( $\mathrm{pH} 4-12)$ with a maximum activity at $\mathrm{pH} 8.5^{[21]}$ Hussain et al. also reported that the serine peptidase of the fungus $A$. terreus showed optimum activity at $\mathrm{pH} 8.5$, using casein as a substrate. ${ }^{[1]}$ Another study demonstrated that

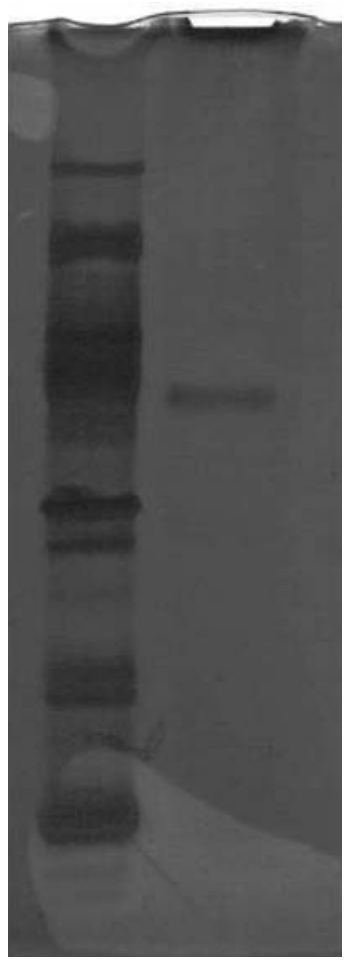

Figure 2. SDS-PAGE electrophoresis gel of a purified pool of ion-exchange chromatography from $A$. terreus. Lane 1: Standard molecular mass marker proteins (from the top): phosphorylase B (94 kD), bovine serum albumin (67 kD), ovalbumin (43 kD), carbonate dehydratase (30 kD), trypsin inhibitor (20 kD), and a-lactoalbumin (14.4 kD). Lane 2: purified peptidase. The gel was stained with silver nitrate and analyzed by software Image Lab version 3.0 (Bio-Rad). a serine peptidase isolated from fungus Hirsutella rhossiliensis OWVT-1 showed optimum activity at $\mathrm{pH} 7 .^{[22]}$

The effect of temperature on peptidase activity was measured between $25^{\circ} \mathrm{C}$ and $55^{\circ} \mathrm{C}$, and showed maximum activity at $45^{\circ} \mathrm{C}$ (Figure $3 \mathrm{~b}$ ), and the peptidase was shown to be sensitive at increases in temperature above $45^{\circ} \mathrm{C}$. The optimum temperature of the peptidase produced by fungus $H$. rhossiliensis OWVT-1 was determined to be at $40^{\circ} \mathrm{C} .^{[22]}$ The serine peptidase of fungi Aspergillus fumigatus showed maximum activity at $37^{\circ} \mathrm{C} .^{[21]}$ In another study, the optimum temperature of the fungi $A$. terreus isolated was $40^{\circ} \mathrm{C} .^{[1]}$ Fungal peptidases show an optimum temperature range from $40^{\circ} \mathrm{C}$ to $60^{\circ} \mathrm{C}$. $^{[23]}$

Looking at the effect of inhibitors, PMSF reduced the peptidase activity by $99 \%$, compared to the control (Table 2 ). Due to inhibition of peptidase by PMSF and the activity maintained in the presence of other inhibitors, the peptidase was classified as a serine peptidase. The increased activity of $15 \%$ in the presence of EDTA probably occurred due to adsorption of ions that can cause inhibition of peptidases. The other authors Stefanova et al. identified in A. terreus two different classes of peptidases: serine thiol dependent ones and metallopeptidases. ${ }^{[7]}$

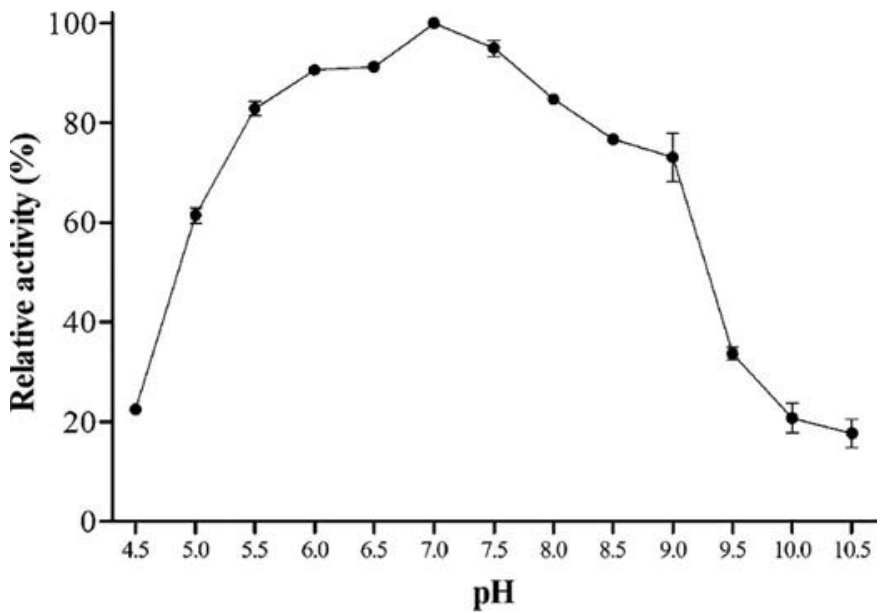

(a)

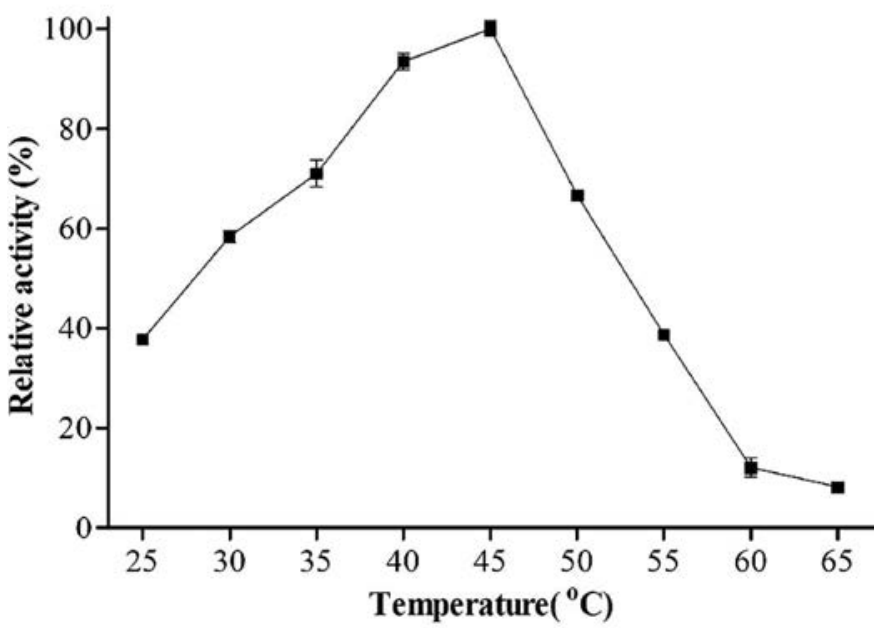

(b)

Figure 3. (a) Influence of $\mathrm{pH}$ on peptidase activity. The activity was determined in different buffers of varying $\mathrm{pH}$ values at $40^{\circ} \mathrm{C}$, using azocasein as substrate. (b) Influence of temperature on purified peptidase activity. The activity was determined in $50 \mathrm{mM}$ HEPES buffer, $\mathrm{pH} 7.0$, using azocasein as substrate. 
Table 2. Effect of inhibitors on peptidase activity from A. terreus.

\begin{tabular}{lc}
\hline Inhibitor $(10 \mathrm{mM})$ & Relative activity $(\%)$ \\
\hline None & 100 \\
EDTA & 115 \\
IAA & 78 \\
PMSF & 1 \\
\hline
\end{tabular}

Table 3. Effect of different ions on the activity of serine peptidase from A. terreus.

\begin{tabular}{lc}
\hline lons & Residual activity (\%) \\
\hline Control & $100 \pm 0.7$ \\
$\mathrm{MnCl}_{2}$ & $102.7 \pm 2.2$ \\
$\mathrm{CaCl}_{2}$ & $102.6 \pm 1,9$ \\
$\mathrm{CuCl}_{2}$ & $89.2 \pm 1.3$ \\
$\mathrm{BaCl}_{2}$ & $79.8 \pm 3$ \\
$\mathrm{MgCl}_{2}$ & $73.2 \pm 0.5$ \\
$\mathrm{CoCl}$ & $72.3 \pm 2.6$ \\
$\mathrm{KCl}$ & $69.2 \pm 5.2$ \\
$\mathrm{NaCl}$ & $67.7 \pm 2.6$ \\
$\mathrm{AlCl}$ & $54.3 \pm 1.2$ \\
$\mathrm{LiCl}$ & $2.6 \pm 0.6$ \\
\hline
\end{tabular}

The peptidase activity presented different levels of inhibition in the incubation with $5 \mathrm{mM}$ of $\mathrm{CuCl}_{2}(11 \%)$, $\mathrm{BaCl}_{2}(20 \%), \mathrm{MgCl}_{2}(27 \%), \mathrm{CoCl}_{2}(28 \%), \mathrm{KCl}(31 \%), \mathrm{NaCl}$ $(32 \%)$, and $\mathrm{AlCl}_{3}(46 \%)$, and the activity was totality inhibited by $\mathrm{LiCl}(97 \%)$ (Table 3$)$.

Hussain et al. ${ }^{[1]}$ reported that the peptidase of fungus A. terreus showed little increase in activity in the presence of $\mathrm{Mg}^{2+}, \mathrm{Mn}^{2+}$, and $\mathrm{Fe}^{3+}$. In the conditions used in this study, no ion activates the peptidase, whereas the peptidase of fungi Aspergillus clavatus ES1 showed an increase in activity in the presence of calcium and magnesium sulfate. ${ }^{[24]}$ Interestingly, the increase of the activity of the peptidase in the presence of EDTA can be explained by the inactivation observed in the presence of the ions.

Figure $4 \mathrm{a}$ shows the effect of the reducing agent DTT on proteolytic activity. The peptidase showed $50 \%$ activity when exposed to a range of $20 \mathrm{mM}$ to $100 \mathrm{mM}$ of DTT; with an increase in concentration of DTT, the activity was maintained at $40 \%$. The peptidase was inhibited by DTT, and this fact indicates that the reducing agent promotes denaturation through the breakdown of the disulfide bonds of the enzyme. ${ }^{[23]}$

The effect of surfactants SDS and CTAB on enzyme activity showed that the enzyme is sensitive to an increase in surfactant concentration. The enzyme was totally inhibited by $0.1 \%$ $\mathrm{CTAB}$ and $0.5 \%$ SDS (Figure $4 \mathrm{~b}$ ), suggesting that cationic or anionic exchange promotes denaturation. The acid peptidase of $A$. clavatus with $2 \mathrm{mM}$ SDS reduces activity by $50 \%$, which indicates breaking of hydrophobic interactions of the native structure. ${ }^{[18]}$ The alkaline serine peptidase produced by $A$. clavatus ES1 was $10 \%$ inhibited in $0.1 \%$ SDS. $^{[24]}$

Urea is considered a chaotropic agent and can be associated with the rupture of hydrogen bonds present in enzymes. ${ }^{[25]}$ Figure $4 \mathrm{c}$ shows that the peptidase activity was not affected by $1 M$ urea. Merheb-Dinni et al. showed that metallopeptidase increased in activity with an increase of urea concentration until $4.5 \mathrm{M}$, using casein as substrate. ${ }^{[23]}$

According to the nomenclature described by Schechter and Berger (1967) the catalytic site is divided into subsites (e.g., papain contains seven subsites). Each subsite accommodates an amino acid residue of the substrate. The mapping of subsites reports the size, preference, and other physical and chemical parameters of the active site. ${ }^{[26]}$

Table 4 shows kinetics of subsites of $S_{1}, S_{2}$, and $S_{3}$ of purified enzyme. The study kinetics parameters of the $S_{1}$

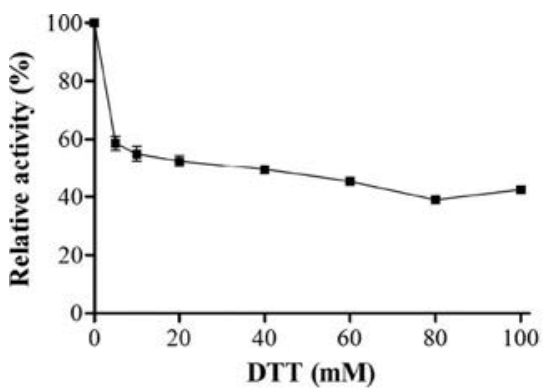

(a)

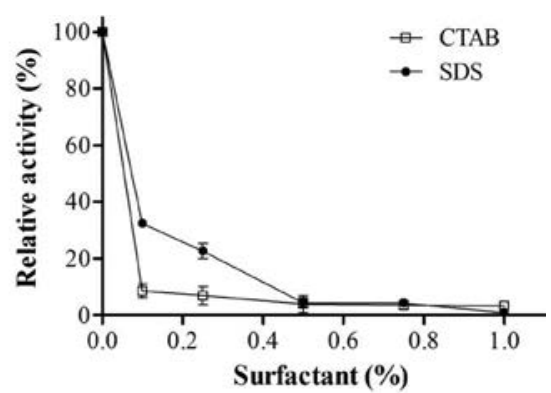

(b)

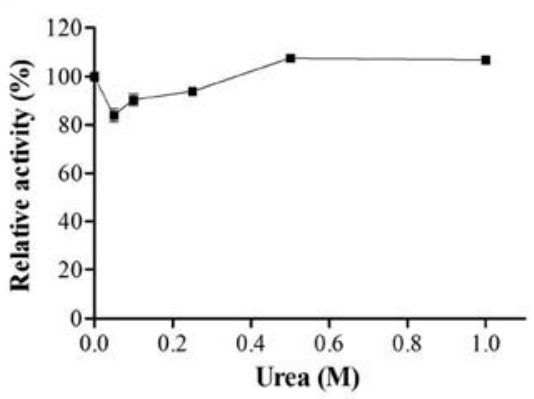

(c)

Figure 4. (a) Effect of DTT on peptidase activity. The activity was determined in $50 \mathrm{~m} M$ Hepes Buffer at $40^{\circ} \mathrm{C}$ using azocasein as substrate. (b) Effect of cationic (CTAB) and anionic (SDS) surfactants on peptidase activity. The activity was determined in $50 \mathrm{mM}$ HEPES buffer at $40^{\circ} \mathrm{C}$ using azocasein as substrate. CTAB: cetyl trimethyl ammonium bromide; SDS: sodium lauryl sulfate. (c) Effect of urea on peptidase activity. The activity was determined in $50 \mathrm{mM} \mathrm{HEPES} \mathrm{buffer} \mathrm{at} 40^{\circ} \mathrm{C}$ using azocasein as substrate. 
Table 4. Kinetic parameter $\left(\mathrm{k}_{\mathrm{cat}} / \mathrm{k}_{\mathrm{M}}\right)$ for the hydrolysis of the substrates Abz-KLRSSKQ-EDDnp, with replacements in the $P_{1}, P_{2}$, and $P_{3}$ position of purified serine peptidase from $A$. terreus.

\begin{tabular}{|c|c|}
\hline Substrate $P_{1}$ position & $\mathrm{k}_{\mathrm{cat}} / \mathrm{K}_{\mathrm{m}}\left(\mathrm{m} M^{-1} \mathrm{~s}^{-1}\right)$ \\
\hline Abz-KLDSSKQ-EDDnp & $68.36 \pm 0.12$ \\
\hline Abz-KLESSKQ-EDDnp & $222.7 \pm 3.33$ \\
\hline Abz-KLFSSKQ-EDDnp & $228.9 \pm 1.04$ \\
\hline Abz-KLHSSKQ-EDDnp & $275.2 \pm 0.3$ \\
\hline Abz-KLISSKQ-EDDnp & Nonhydrolysis \\
\hline Abz-KLMSSKQ-EDDnp & $205.8 \pm 1.71$ \\
\hline Abz-KLRSSKQ-EDDnp & $258.5 \pm 0.37$ \\
\hline Abz-KLSSSKQ-EDDnp & $263.6 \pm 2.8$ \\
\hline Abz-KLTSSKQ-EDDnp & $305.5 \pm 0.07$ \\
\hline Abz-KLYSSKQ-EDDnp & $363.4 \pm 2.59$ \\
\hline Substrate $\mathrm{P}_{2}$ position & $\mathrm{k}_{\mathrm{cat}} / \mathrm{K}_{\mathrm{m}}\left(\mathrm{m} M^{-1} \mathrm{~s}^{-1}\right)$ \\
\hline Abz-KDRSSKQ-EDDnp & Nonhydrolysis \\
\hline Abz-KERSSKQ-EDDnp & Nonhydrolysis \\
\hline Abz-KFRSSKQ-EDDnp & $74.7 \pm 0.76$ \\
\hline Abz-KHRSSKQ-EDDnp & Nonhydrolysis \\
\hline Abz-KIRSSKQ-EDDnp & $98 \pm 1.31$ \\
\hline Abz-KMRSSKQ-EDDnp & $12.4 \pm 0.05$ \\
\hline Abz-KRRSSKQ-EDDnp & Nonhydrolysis \\
\hline Abz-KSRSSKQ-EDDnp & Nonhydrolysis \\
\hline Abz-KLTRSSKQ-EDDnp & Nonhydrolysis \\
\hline Abz-KLYSSKQ-EDDnp & $16.5 \pm 0.17$ \\
\hline Substrate $P_{3}$ position & $\mathrm{k}_{\mathrm{cat}} / \mathrm{K}_{\mathrm{m}}\left(\mathrm{m} M^{-1} \mathrm{~s}^{-1}\right)$ \\
\hline Abz-DLRSSKQ-EDDnp & $201 \pm 0.17$ \\
\hline Abz-ELRSSKQ-EDDnp & $242.7 \pm 0.92$ \\
\hline Abz-FLRSSKQ-EDDnp & $207.3 \pm 1.39$ \\
\hline Abz-HLRSSKQ-EDDnp & $263.6 \pm 0.84$ \\
\hline Abz-ILRSSKQ-EDDnp & $245.7 \pm 2.02$ \\
\hline Abz-MLRSSKQ-EDDnp & $231.7 \pm 1.01$ \\
\hline Abz-RLRSSKQ-EDDnp & $236.4 \pm 1.34$ \\
\hline Abz-SLRSSKQ-EDDnp & $318.7 \pm 3.17$ \\
\hline Abz-TLRSSKQ-EDDnp & $170.7 \pm 0.13$ \\
\hline Abz-YLRSSKQ-EDDnp & $43.7 \pm 0.07$ \\
\hline
\end{tabular}

subsite showed hydrolysis when the substrate contained amino acid Tyr in this subsite, with a catalytic efficiency of $363.4 \pm 2.58$ $\mathrm{m}^{-1} \mathrm{~s}^{-1}$, followed by Thr with $305.5 \pm 0.07 \mathrm{mM}^{-1} \mathrm{~s}^{-1}$. Subsite $S_{1}$ showed a preference for aromatic amino acids in the substrates, which led to the highest degree of hydrolysis. In substrate containing isoleucin the enzyme showed no activity, possibly due to the size of side chain of the amino acid.

Analyzing the peptidase behavior to the $S_{2}$ subsite, the peptidase did not show high hydrolysis of the substrates assayed. Only substrates that contained nonpolar amino acids (Ile, Phe, and Met) and Tyr (polar) showed hydrolysis, with catalytic efficiency of $98 \pm 2.02,74.7 \pm 0.76,12.4 \pm 0.06$, and $16.5 \pm 0.17 \mathrm{mM}^{-1} \mathrm{~s}^{-1}$, respectively.

Subsite $\mathrm{S}_{3}$, displayed highest catalytic efficiency to Ser and His with $318.7 \pm 3.17 \mathrm{mM}^{-1} \mathrm{~s}^{-1}$ and $263.6 \pm 0.84 \mathrm{mM}^{-1} \mathrm{~s}^{-1}$. This subsite too showed preference for substrates contained polar amino acids. In selectivity order by tested substrates, the $S_{3}$ subsite is less selective than the $S_{1}$ subsite, and subsite $S_{2}$ is more selective than the $S_{1}$ and $S_{3}$ subsites.

In general, this peptidase showed low catalytic efficiency when compared with the serine peptidase of Aspergillus fumigatus, ${ }^{[27]}$ Penicillium waksmanii, ${ }^{[16]}$ and Myceliophtora spp. ${ }^{[28]}$

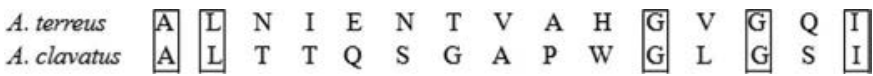

Figure 5. Comparison of $\mathrm{N}$-terminal amino acid sequence of the purified peptidase from $A$. terreus with $A$. clavatus ES1.
The N-terminal sequence of the first 15 amino acid residues of the enzyme isolated from this fungus was ALNIENTVAHGVGQI. Figure 5 demonstrates that the peptidase sequence showed $33 \%$ identity with the fungi $A$. clavatus $\mathrm{ES}^{[24]}$ peptidase sequence.

\section{Conclusions}

The purification process for the peptidase produced by Aspergillus terreus employed in this work was effective and it was performed in three chromatographic steps. The presence of metallic ions had a negative effect on peptidase activity; however, in the presence of EDTA we observed an increase of $15 \%$ in its activity. In the kinetics assays, the substrate Abz-KLRSSKQ-EDDnp with replacements in the $\mathrm{P}_{1}, \mathrm{P}_{2}$, and $\mathrm{P}_{3}$ positions, respectively, displayed that the subsite $\mathrm{S}_{2}$ is more specific than subsites $S_{1}$ and $S_{3}$, but the $S_{1}$ subsite showed highest catalytic efficiency. The kinetics parameters showed that the peptidase has a preference for substrates containing polar amino acids in $\mathrm{P}_{1}$ (Tyr and Trp).

\section{Funding}

The authors acknowledge the financial support provided by the Fundação de Amparo à Pesquisa do Estado de São Paulo (FAPESP) (2011/06986-0 and 2012/24703-8) and by the Conselho Nacional de Desenvolvimento Científico e Tecnológico (CNPq) (308078/2012-8).

\section{References}

[1] Hussain, A.; Mannan, A.; Zubair, H.; Mirza, B. Purification and Characterization of Alkaline Protease From Aspergillus terreus. J. Chem. Soc. Pak. 2010, 32, 497-504.

[2] Rao, M.B.; Tanksale, A.M.; Ghatge, M.S.; Deshpande, V.V. Molecular and Biotechnological Aspects of Microbial Proteases. Microbiol. Mol. Biol. Rev. 1998, 62, 597-635.

[3] Chen, X.G.; Stabnikova, O.; Tay, J.H.; Wang, J.Y.; Tay, S.T. Thermoactive Extracellular Proteases of Geobacillus caldoproteolyticus, sp. nov., from sewage sludge. Extremophiles 2004, 8, 489-498.

[4] Kumar, C.G.; Takagi, H. Microbial Alkaline Proteases: From a Bioindustrial Viewpoint. Biotechnol. Adv. 1999, 17, 561-594.

[5] Lei, F.; Cui, C.; Zhao, Q.; Sun-Waterhouse, D.; Zhao, M. Evaluation of the Hydrolysis Specificity of Protease From Marine Exiguobacterium sp. SWJS2 Via Free Amino Acid Analysis. Appl. Biochem. Biotechnol. 2014, 174, 1260-1271.

[6] Biesebeke, R.; Record, E.; van Biezen, N.; Heerikhuisen, M.; Franken, A.; Punt, P.J.; van den Hondel, C.A. Branching Mutants of Aspergillus oryzae With Improved Amylase and Protease Production on Solid Substrates. Appl. Microbiol. Biotechnol. 2005, 69, 44-50.

[7] Stefanova, M.E.; Beletskaya, O.P.; Kulaev, I.S. Characterization of Two Extracellular Proteinases From Aspergillus terreus and Their Role in the Formation of Low Molecular Weight Endoglucanases. Process Biochem. 1997, 32, 685-689.

[8] Tran, L.H.; Nagano, H. Isolation and Characteristics of Bacillus subtilis CN2 and Its Collagenase Production. J. Food Sci. 2002, 67, 1184-1187.

[9] Sarath, G.; de la Motte, R.S.; Wagner, F.W. Protease Assay Methods. In Proteolytic Enzymes: A Practical Approach. Beynon, R.J. Bond, J.S. Eds.; IRL Press: Oxford, UK, 1989; pp. 25-56.

[10] Ducros, E.; Ferrari, M.; Pellegrino, M.; Raspanti, C.; Bogni, C. Effect of Aeration and Agitation on the Protease Production by Staphylococcus aureus Mutant RC128 in a Stirred Tank Bioreactor. Bioprocess. Biosyst. Eng. 2009, 32, 143-148.

[11] Morita, Y.; Hasan, Q.; Sakaguchi, T.; Murakami, Y.; Yokoyama, K.; Tamiya, E. Properties of a Cold-Active Protease From Psychrotrophic 
Flavobacterium balustinum P104. Appl. Microbiol. Biotechnol. 1998, 50, 669-675.

[12] Bradford, M.M. A Rapid and Sensitive Method for the Quantitation of Microgram Quantities of Protein Utilizing the Principle of Protein-Dye Binding. Anal. Biochem. 1976, 72, 248-254.

[13] Laemmli, U.K. Cleavage of Structural Proteins During the Assembly of the Head of Bacteriophage T4. Nature 1970, 227, 680-685.

[14] Blum, H.; Beier, H.; Gross, H. Improved silver staining of plant proteins, RNA and DNA in polyacrylamide gels. Electrophoresis, 1987, 8, 93-99.

[15] Dunn, B.M. Determination of Protease Mechanism. In Proteolytic Enzymes: A Practical Approach. Beynon, R.J., Bond, J.S., Eds.; IRL Press: Oxford, UK, 1989; pp. 57-81.

[16] Graminho, E.R.; da Silva, R.R.; de Freitas Cabral, T.P.; Arantes, E.C.; da Rosa, N.G.; Juliano, L.; Okamoto, D.N.; Goncalves de Oliveira, L.C.; Kondo, M.Y.; Juliano, M.A.; Cabral, H. Purification, Characterization, and Specificity Determination of a New Serine Protease Secreted by Penicillium waksmanii. Appl. Biochem. Biotechnol. 2013, 169, 201-214.

[17] Edman, P.; Begg, G. A Protein Sequenator. Eur. J. Biochem. 1967, $1,80-91$.

[18] Sampaio e Silva, T.A.; Knob, A.; Tremacoldi, C.R.; Brochetto-Braga, M.R.; Carmona, E.C. Purification and Some Properties of an Extracellular Acid Protease From Aspergillus clavatus. World J. Microb. Biotechnol. 2011, 27, 2491-2497.

[19] Stefanova, M.E. Purification of Two Proteinases From Aspergillus terreus by Affinity Chromatography. J. Chromatogr. A 1993, 639, 346-351.

[20] Gupta, R.; Beg, Q.K.; Khan, S.; Chauhan, B. An Overview on Fermentation, Downstream Processing and Properties of Microbial Alkaline Proteases. Appl. Microbiol. Biotechnol. 2002, 60, 381-95.
[21] Chakrabarti, S.K.; Matsumura, N.; Ranu, R.S. Purification and Characterization of an Extracellular Alkaline Serine Protease From Aspergillus terreus (IJIRA 6.2). Curr. Microbiol. 2000, 40, 239-244.

[22] Wang, B.; Wu, W.; Liu, X. Purification and Characterization of a Neutral Serine Protease With Nematicidal Activity From Hirsutella rhossiliensis. Mycopathologia 2007, 163, 169-176.

[23] Merheb-Dini, C.; Cabral, H.; Leite, R.S.; Zanphorlin, L.M.; Okamoto, D.N.; Rodriguez, G.O.; Juliano, L.; Arantes, E.C.; Gomes, E.; da Silva, R. Biochemical and Functional Characterization of a Metalloprotease From the Thermophilic Fungus Thermoascus aurantiacus. J. Agric. Food Chem. 2009, 57, 9210-9217.

[24] Hajji, M.; Kanoun, S.; Nasri, M.; Gharsallah, N. Purification and Characterization of an Alkaline Serine-Protease Produced by a New Isolated Aspergillus clavatus ES1. Process Biochem. 2007, 42, 791797.

[25] Rocco, A.G.; Mollica, L.; Ricchiuto, P.; Baptista, A.M.; Gianazza, E.; Eberini, I. Characterization of the Protein Unfolding Processes Induced by Urea and Temperature. Biophys. J. 2008, 94, 2241-2251.

[26] Schechter, I.; Berger, A. On the Size of the Active Site in Proteases.I. Papain. Biochem. Biophys. Res. Commun. 1967, 27, 157-162.

[27] Silva, R.R.; Caetano, R.C.; Okamoto, D.N.; Oliveira, L.C.G.; Bertolin, T.C.; Juliano, M.A.; Juliano, J.; Oliveira, A.H.C.; Rosa, J.C.; Cabral, H. The Identification and Biochemical Properties of the Catalytic Specificity of a Serine Peptidase Secreted by Aspergillus fumigatus Fresenius. Protein Peptide Lett. 2014, 21, 663-671.

[28] Zanphorlin, L.M.; Cabral, H.; Arantes, E.; Assis, D.; Juliano, L.; Juliano, M.A.; Da-Silva, R.; Gomes, E.; Bonilla-Rodriguez, G.O. Purification and Characterization of a New Alkaline Serine Protease From the Thermophilic Fungus Myceliophthora sp. Process Biochem. 2011, 46, 2137-2143. 